\title{
Barriers to Access to and Usage of Financial Services in Ethiopia
}

\author{
K. Sambasiva Rao \\ Professor of Finance \& Accounting, Department of Commerce \& Mgt Studies, \\ Andhra University, Visakhapatnam-530003, Andhra Pradesh, India \\ E-mail: Profksrao@gmail.com
}

Andualem Ufo Baza

Ph.D Research Scholar, Department of Commerce \& Mgt Studies, Andhra University, Visakhapatnam-530003, Andhra Pradesh, India E-mail: bazzafin.au@gmail.com

Received: February 13, 2017 Accepted: March 29, 2017

doi:10.5296/ber.v7i1.11034 URL: https://doi.org/10.5296/ber.v7i1.11034

\begin{abstract}
We study the interplay between financial exclusion and barriers to inclusion. Our model shows that financially excluded individuals are exposed to barriers to inclusion that prohibit their access to financial services even in absence of voluntary exclusion. We call these situation "involuntary exclusion," since people lack access to and use of financial services due to barriers to inclusion that are otherwise overlooked social exclusion. We show that financial exclusion are more likely to occur when lack of access to physical point of financial services, poverty, lack of credit, prohibitive fixed cost of transacting at financial institution, legal and regulatory barriers and low competition among financial institutions. We analyze financial exclusion as a function of barriers to inclusion, examining the trade-off between unbanked adults and barriers to banking. We verify the model's prediction that financial exclusion is more likely to occur among low income individuals in which assets holdings are low, as well as individuals who are too far away from physical point of access and those individuals who cannot afford bank fixed charges, than others. We also show that individuals are more likely to be financially excluded (relative to others) in low income groups in which barriers to inclusion are more frequent.
\end{abstract}

Keywords: Financial exclusion, Cost barriers, Credit barriers, Distance barriers, Financial 
barriers, Ethiopia

\section{Introduction}

Existing research argues barriers to financial inclusion is a key determinant of financial exclusion (see, eg., Galor and Zeira 1993; and Beck, Demirguc-Kunt, and Martinez Peria 2005; Demirguc-Kunt and Klapper 2012a; Allen, Demirguc-Kunt, and others 2012); World Bank 2008; Demirguc-Kunt and Klapper 2012b; World Bank 2014a). Given those barriers to inclusion such as lack of money, distance, cost, credit, and documentation requirements are the most essential obstacle to inclusion. One could expect that such barriers could be an essential deriver of financial exclusion. Our study identifies the existence of these barriers to financial inclusion in Ethiopia and build up a theoretical relation between financial exclusion and barriers to inclusion. Our model explains why a financially excluded household might be exposed to barriers to inclusion that prohibit their access to financial services even when there is no voluntary exclusion. We call this type of exclusion an involuntary exclusion. The model adds to our understanding of financial inclusion by showing how these barriers to inclusion might dominate the other kinds of barriers such as legal hurdles, asymmetric information, contract enforcement costs, lack of competition and other market failures in the financial inclusion. In particular, it shows that lack of money, distance, cost, credit, and documentation barriers can be particularly essential causes of exclusion.

Evidence suggests that individuals involuntarily excluded on their access to financial services when physical point of financial services are too far away and too expensive to have an account, discrimination against certain groups, contractual as well as asymmetric information (World Bank, 2014). They are different from those who have access, but choose not to use financial services and those do not need financial institution services.

We begin with some controversial research questions such as; (1) what are the barriers to financial inclusion in Ethiopia? (2) What determines exclusion? The overall goal is to examine the barriers to financial inclusion in Ethiopia. We identify and address the barriers to financial inclusion. The main objective of this study is fivefold. The first goal is to identify and measure the distance barriers in Ethiopia. The second goal is to identify and measure the cost barriers in Ethiopia. The third goal is to identify and measure the credit barriers in Ethiopia. The fourth goal is to identify and measure the other barriers to inclusion in Ethiopia. The fifth goal is examine determinants of barriers to financial inclusion in Ethiopia. The final goal is to analyze and document the significance of distance, cost, credit and other barriers in financial inclusion policy decision making. We use the methodology that is suitable to identify barriers to inclusion and to examine the interplay between financial exclusion and barriers to inclusion. Section 2 reviews the literature. Section 3 describes our research approach, sample, and hypothesis. Section 4 presents the results of our analysis. Section 5 concludes and recommends.

\section{Literature Review}

A large empirical literature on barriers to financial inclusion has emerged in recent years. A partial list of papers includes [(see, eg., Galor and Zeira 1993; and Beck, Demirguc-Kunt, and 
Martinez Peria 2005; Demirguc-Kunt and Klapper 2012a; Allen, Demirguc-Kunt, and others 2012); World Bank 2008; Demirguc-Kunt and Klapper 2012b; World Bank 2014a)] provides a useful review of this literature. In contrast to literature on financial inclusion, the literature on barriers to inclusion is scant. Demirguc-Kunt and Klapper (2012a) study distance barriers. Examining the developing countries financial inclusion, they mentioned that there is a significant relationship between distance as a self-reported barrier and objective measures of providers, such as bank branch penetration.

Allen, Demirguc-Kunt, and others (2012) use the 2011 Global Findex database of 123 economies and over 124,000people found that high cost of account is the barrier to financial inclusion. Their finding associated high cost of accounts with lack of competition and under developed infrastructure in the economy. Demirguc-Kunt and Klapper (2012a) find high costs and fixed charges of transaction and annual fees tend to make small transactions unaffordable for majority parts of the adults in low-income economies. The empirical evidences shows that barriers to financial inclusion among others are regulations requiring onerous paperwork, travel distance, legal hurdles, or other market failures (World Bank 2008; Demirguc-Kunt and Klapper 2012b; World Bank 2014a). The studies conducted by various researchers found that transactions costs, informational asymmetries, and contract enforcement costs are barriers to financial inclusion (Galor and Zeira 1993; and Beck, Demirguc-Kunt, and Martinez Peria 2005; Demirguc-Kunt and Klapper 2012a; Allen, Demirguc-Kunt, and others 2012). World Bank (2014a) study found lack of trust in formal financial institutions is a nontrivial obstacle to broader inclusion and one that is difficult to address it immediately.

\section{Research Approach, Sample Choice and Hypothesis}

Below, we explain the methodology and data that we use in our analysis.

\subsection{Survey Methodology}

In this study, we employ four measures of barriers to access and use that are categorized into four. These are measures of access barriers also known as distance to access points of financial services has three measures: (1) average distance to bank branch (2) average distance to ATMs (3) Average distance to mobile money agents. The existence of too far distance (1-3) reflects existence of distance barrier to access financial services. We also identify and analyze the money cost and time cost to access bank branches and other access points to financial services.

The measures of cost barriers also known as cost of using an account have three measures: (1) average cost of opening a basic current/saving account (2) average cost of maintaining a bank account (3) average cost of credit transfers. The existence of (1-3) reflects existence of cost barrier to use financial services. The credit barrier measures are also known as barriers getting credit are measured: (1) 'distance to frontier score', which measures the strength of credit reporting systems and effectiveness of collateral and bankruptcy laws in facilitating lending. The distance to credit frontier score (DCFS) helps in measuring the absolute level of regulatory performance and how it improves overtime. We used the survey instruments to identify the existence of other barriers in Ethiopia. The data related to barriers to access and 
use of financial services was collected from survey of demand side which was conducted by the researcher in 2016. The demand side survey consists of 340 randomly selected adults from 34kebele in Ethiopia using multi-stage cluster sampling and the supply side data collected from the National Bank of Ethiopia and Commercial Banks.

\subsection{Empirical Methodology}

\subsubsection{Econometric Model on Determinants of Barriers to Financial Inclusion}

In this study, researchers employed regression analysis to examine the robust determinants of barriers to financial inclusion in Ethiopia. The study relied on the relationship between financial exclusion and barriers to inclusion. We depend on the demand side survey response of 2015/16 conducted by the researchers in jurisdiction. The regression model for the expanded set of explanatory variables is:

$$
\begin{gathered}
\mathrm{y}_{i}=\gamma+\beta_{1} * \text { lack money other }_{i}+\beta_{2} * \text { lack money only }_{i}+\beta_{3} * \text { too far away }_{i}+\beta_{4} * \text { too expensive }_{i}+\beta_{5} * \text { lack } \\
\text { document }_{i}+\beta_{6} * \text { family account }_{i}+\beta_{7} * \text { lack trust }_{i}+\beta_{8} * \text { Religious }_{i}+\varepsilon_{i}
\end{gathered}
$$

Where the dependent variable $\left(y_{\dot{i}}\right)$ represents the measure of financial exclusion. We briefly explain all our variables below. Researchers selected the most important indicator of financial exclusion and explanatory variables from demand side survey response of 2016, these are in line with the literature on barriers to financial inclusion. The main goal of this study is to examine the interplay between the financial exclusion and barriers to inclusion.

\subsubsection{Explanatory Variables and Hypothesis}

Below the researchers briefly explain the underlying explanatory variables:

Lack of Money with other reason: A larger percent of population appears to be financially excluded due to lack of money to use account in jurisdiction. Therefore, there is a positive and significant relationship between financial exclusion and lack of enough money with other reasons.

Lack of Money only reason: those adults who reported lack of money as only reason for financial exclusion. In this case poverty is real reason for exclusion. Therefore, there is a positive and significant relationship between financial exclusion and lack of enough money as only reason.

Too far away: mean that those adults who reported too far away from financial institutions like Banks and MFIs. Therefore, there is a positive and significant relationship between financial exclusion and distance to financial institutions.

Too expensive: means those adults who reported ownership of bank account are unaffordable. Therefore, there is a positive and significant relationship between financial exclusion and unaffordability of financial services.

Lack of necessary documents: means those adults who reported lack of necessary documents 
limit them from owning bank account. Therefore, there is a positive and significant relationship between financial exclusion and lack of necessary documents.

Family member has an account: mean that those adults who reported someone else in their family already has an account. They are prohibited to own account due to this. Therefore, there is a positive and significant relationship between financial exclusion and family member already have an account.

Lack of trust: represents those adults who reported lack of trust in financial institutions limited them to own bank account. Therefore, there is a positive and significant relationship between financial exclusion and lack of trust.

Religious reason: means those adults who reported their religion prohibit them from owning and using normal account. They need some special financial institutions to have an account. Therefore, there is a positive and significant relationship between financial exclusion and religious reasons.

In our regression analysis we have employed the variables $(0 / 1)$, where ' 0 ' represents those variables with 'no' response and 1 represent those variable with 'yes' response.

\section{Results}

\subsection{Survey Results}

We find evidence that in Ethiopia, in 2016, about 36.5million adults (66.14percent adults) are unbanked, without an account. The evidence shows that the reason for such exclusion are lack of money, distance, cost and lack of necessary documentations are important barriers to financial inclusion. The evidence indicates the structure and regulation of financial system is main obstacle to credit exclusion. We identified low product diversification as well as market failure is reason for deposit exclusion of low-income individuals.

\subsubsection{Distance Barriers}

We find that in Ethiopia on average adults travel $19.14 \mathrm{~km}$ to reach bank branch. The evidence shows that the average transportation cost is Birr12 and the average travel time if adults walk is 90minutes. We show evidences that ATMs in Ethiopia are located along with the bank branches. We find that the mean distance to ATMs is $19.17 \mathrm{~km}$ and the mean transportation cost is Birr 12 and if adults walk it takes in average 91.3minutes. The evidence shows that mobile money centers are rarely available, but in some areas they are available in average distance of $26.31 \mathrm{~km}$ and average transportation cost of Birr 15 (Table 1).

Table 1. Distance barriers in Ethiopia

\begin{tabular}{|l|c|c|c|}
\hline & & \multicolumn{2}{|c|}{ Mean } \\
\hline Distance/cost & $M D(S D)$ & Distance(Km) & Cost(in Birr) \\
\hline Bank branch & & 19.14 & 12 \\
\hline $\begin{array}{l}\text { Bank ATMs } \\
\text { Mobile Money agent }\end{array}$ & & 19.17 & 12 \\
\hline
\end{tabular}

Source: Author Analysis of distance barriers in Ethiopia 
In 2016 survey, in jurisdiction, 30percent of adults not having an account reported distance as their main barrier to inclusion. The evidence shows that distance is the second main barrier to financial inclusion.

\subsubsection{Cost Barriers}

We show evidence that the cost of opening a checking account in Ethiopia is Birr 1000 and that of saving account is Birr 25 (see Table 2). The evidence shows that an average cost of maintaining a bank account is zero. We show evidence that the average cost of credit transfer is Birr 23 up to Birr 4,000 on over-the counter transaction. In Ethiopia price barrier is the third barrier that prohibits individuals to have bank account. In jurisdiction, 25 percent of adults without an account are reported too expensive to own an account. The supply side survey identified that lack of competition and low physical and institutional infrastructure are barriers to financial inclusion.

Table 2. Cost barriers to inclusion in Ethiopia

\begin{tabular}{|l|l|ll|l|}
\hline & & \multicolumn{3}{|c|}{ Mean (in Birr) } \\
\hline Costs & $M D(S D)$ & UL & M & LL \\
\hline Opening saving account & & 25 & 25 & 0 \\
\hline Opening checking account & & 1000 & 1000 & 1000 \\
\hline Transfer credit (with account) & & 23 & 0 & 0 \\
\hline Over the counter transfer & & & 23 & 23 \\
\hline
\end{tabular}

Source: Author's Analysis of terms and tariffs of Commercial banks in Ethiopia

\subsubsection{Credit Barriers}

The evidence shows that distance to frontier score for Ethiopia is 15 . This shows a declining trend from the earlier periods. The access to credit in the jurisdiction is limited. This show that the distance to credit frontier was very far in Ethiopia. In Ethiopia firm own account at formal financial institution is 92 percent, but the evidence shows those with an outstanding loan or line of credit were only 29.6 percent in 2016. This shows that more than 70percent of firms in the jurisdiction are credit constrained. The proportion of loans requiring collateral is 84.4 percent in 2016(see Table 3). This analysis indicates collateral requirement is real barrier to credit in jurisdiction. The evidences show that the Percent of firms using banks to finance investments were only 12.9 percent in 2016. That means 88.1percent of firms are out of bank credit to finance their investment in Ethiopia. In jurisdiction, in 2016, the firms who reported access to finance as their main obstacle are 40.4 percent.

Table 3. Credit barriers in Ethiopia

\begin{tabular}{|l|c|c|c|}
\hline & & \multicolumn{2}{|c|}{ Mean } \\
\hline Collateral & $M D(S D)$ & 2011 & 2015 \\
\hline Firms require & 4.1 & 84.4 & 88.5 \\
\hline Firms not require & & 15.6 & 11.5 \\
\hline
\end{tabular}

Source: Author Analysis of barriers to credit in Ethiopia

We find evidence that 99percent of individuals reported it is difficult to get credit from financial institution at time of emergency. The firm level evidence indicates distance to credit 
frontier score was 15 in the year 2015(table 4). This score is deteriorating annually. The evidence shows the access to credit appears to be hard in the jurisdiction.

Table 4. Credit barriers in Ethiopia (distance to frontier score)

\begin{tabular}{|l|c|ll|c|}
\hline & $11 / 15$ & \multicolumn{3}{|c|}{ Mean(score) } \\
\hline Distance to frontier sc & $M D(S D)$ & 2011 & 2013 & 2015 \\
\hline Distance to frontier & $(10)$ & 25 & 50 & 15 \\
\hline & & & & \\
\hline
\end{tabular}

Source: Author's analysis of Global Findex database, distance to frontier score between 0-100 in Ethiopia

\subsubsection{Other Barriers}

The lack of enough money is the prime barrier to financial inclusion in jurisdiction. The lack of necessary document is another barrier after lack of money, distance and cost barriers in Ethiopia. It accounts 18percent of financially excluded adults. We find that KYC is a barrier to inclusion in jurisdiction.

Table 5. Access to finance in Ethiopia

\begin{tabular}{|l|c|c|c|}
\hline & & \multicolumn{2}{|c|}{ Mean } \\
\hline Beaurcratic & $M D(S D)$ & 2011 & 2015 \\
\hline Access to finance & & - & 40.4 \\
\hline & & - & - \\
\hline
\end{tabular}

Source: Author Analysis of World Bank Enterprise survey 2015, barriers to access finance in Ethiopia

We conducted supply side study on barriers to financial inclusion. We interviewed the National Bank of Ethiopia employees of the four directorates: Banking Supervision; Insurance Supervision; Microfinance Supervision; and Payment and Settlement directorate. We find that bureaucratic, limited literacy, problem on design of appropriate financial product, political interference and credit information asymmetries are barriers to financial inclusion in Ethiopia.

\subsection{Econometric Analysis and Regression Output}

We examine the interplay between financial exclusion and barriers to inclusion. Our model shows that financially excluded individuals are exposed to barriers to inclusion that prohibit their access to financial services even in absence of voluntary exclusion. The result of regression shows financially excluded individuals are exposed to barriers such as low income, long travel distance and unaffordable bank fixed costs. The regression results show lack of money, too far away, too expensive, are statistically significant and have positive influence on the financial exclusion, whereas another family members has accounts and religious reasons has no influence on financial exclusion(See table1, Appendix 1). We verify the model's prediction that financial exclusion are more likely to occur among low income individuals(lack of money) in which assets holdings(income) are low, as well as individuals who are too far away from physical point of access and those individuals who cannot afford 
bank fixed charges, than others. We have categorized adults by lack of money as the only reason and lack of money with the other reasons such as cost, distance and other barriers. We examined the link between financial exclusion and lack of money as only reason. The result of regression shows lack of money as only reason is significant and positively correlated with the exclusion. This shows that lack of money is inherent barrier to financial inclusion in jurisdiction. This also shows that individuals are more likely to be financially excluded (relative to others) in low income groups in which barriers to inclusion are more frequent. The coefficient of determination R-square (R2) indicates that $41.88 \%$ behaviour of financial exclusion variable unbanked adults can be explained by the independent variables. Overall, F-statistic 29.73 with p-value 0.0000 indicates that the regression model is feasible.

\section{Conclusion and Recommendations}

This paper focused on identifying and addressing barriers to access to and use of financial services by individuals and firms in Ethiopia. We link financial exclusion to barriers to inclusion. Lack of money and long travel distance are positively correlated with financial exclusion in Ethiopia. We verified that the main obstacles contribute to financial exclusion are lack of enough money, distance, cost and documentation requirements. The poor, youth, rural residents and women appears to face greater constraints for access to financial services in jurisdiction. The evidence shows that 40percent of firms in jurisdiction constrained access to credit and credit as their main barriers. As the evidence shows that it is very hard to access finance for starting and small firms in jurisdiction.

Finally, the analysis of the access and usage of financial services by individuals identified physical, bureaucratic, and financial barriers. It is possible to lower barriers to inclusion through creating inclusive financial environment, healthy competition and expanding innovative technologies. Identifying the underlying cause of exclusion appears to be lessening the barriers.

\section{References}

Allen, F., Demirguc-Kunt, A., Klapper, L., \& Martinez, Peria, M. S. (2012). Foundations of Financial Inclusion. Policy Research Working Paper 6290, World Bank, Washington, DC. http://documents.worldbank.org/curated/en/348241468329061640/The-foundations-of-financ ial-inclusion-understanding-ownership-and-use-of-formal-accounts

Beck, T., Demirguc-Kunt, A., \& Martinez, Peria, M. S. (2005). Reaching out: Access to and Use of Banking Services across countries. World Bank Policy Working paper, 3754. https://doi.org/10.1596/1813-9450-3754

Demirguc-Kunt, A., \& Klapper, L. (2012a). Measuring Financial Inclusion: The Global Findex Database. Policy Research Working Paper, 6025, World Bank, Washington, DC. https://doi.org/10.1596/1813-9450-6025

Demirguc-Kunt, A., \& Klapper, L. (2012b). Financial Inclusion in Africa: An Overview. Policy Research Working Paper 6088, World Bank, Washington, DC.

https://doi.org/10.1596/1813-9450-6088 


\section{Al Macrothink}

Business and Economic Research

ISSN 2162-4860

2017, Vol. 7, No. 1

Galor, O., \& Zeira. J. (1993). Income Distribution and Macroeconomics. Review of Economic Studies, 60, 35-52. https://doi.org/10.2307/2297811

World Bank. (2014a). Global Financial Development Report 2014: Financial Inclusion. Washington, DC: World Bank. http://hdl.handle.net/10986/16238

World Bank. (2015a). World Financial Development database 2015: Financial Inclusion data base. Washington, DC: World Bank.

http://www.worldbank.org/en/publication/gfdr/data/global-financial-development-database

World Bank. (2015b). Enterprise Surveys (http://www.enterprisesurveys.org), The World Bank.

http://www.enterprisesurveys.org/data/exploreeconomies/2015/ethiopia\#firm-characteristics

World Bank. (2015c). The World Development Indicators, The World Bank: The Financial sector Database, World Bank, Washington, DC.

http://databank.worldbank.org/data/download/WDI_csv.zip

\section{Appendix 1: Econometric tests}

Table 1: Linear Regression output

\begin{tabular}{|c|c|c|c|c|c|c|c|c|}
\hline \multirow{2}{*}{ Source } & & & \multirow{2}{*}{\multicolumn{2}{|c|}{ MS }} & \\
\hline & SS & $d f$ & & & \multicolumn{4}{|c|}{ Number of obs $=$} \\
\hline Model & 33.1585321 & 8 & 4.14481651 & & \multicolumn{2}{|c|}{ Prob $>F=$} & \multicolumn{2}{|l|}{0.0000} \\
\hline Residual & 46.0096095 & 330 & .139423059 & & \multicolumn{2}{|c|}{ R-squared } & 0.4188 & \\
\hline & & & & & \multirow{2}{*}{\multicolumn{2}{|c|}{$\begin{array}{ll}\text { Adj R-squared } & = \\
\text { Root MSE } & =\end{array}$}} & 0.4047 & \\
\hline Total & 79.1681416 & 338 & .234225271 & & & & .37339 & \\
\hline \multicolumn{2}{|c|}{ unbankedadultslyesono } & & Coef. & Std. Err. & $\mathrm{t}$ & $P>|t|$ & [95\% Conf. & Interval] \\
\hline \multicolumn{2}{|c|}{ LackofMoneywithotherlyes 0 p } & & .186755 & .0637452 & 2.93 & 0.004 & .0613569 & .3121531 \\
\hline \multirow{2}{*}{\multicolumn{2}{|c|}{$\begin{array}{r}\text { LackofMoneyonlyreason } 1 \text { yesp } \\
\text { Toofarawaylyesono }\end{array}$}} & & .4195829 & .0575379 & 7.29 & 0.000 & .3063956 & .5327702 \\
\hline & & & .3717604 & .0571718 & 6.50 & 0.000 & .2592932 & .4842276 \\
\hline \multicolumn{2}{|c|}{ Tooexpensivelyesono } & & .3188063 & .0618517 & 5.15 & 0.000 & .197133 & .4404796 \\
\hline \multirow{2}{*}{\multicolumn{2}{|c|}{$\begin{array}{r}\text { lackofnecessarydocument } 1 \text { yesp } \\
\text { Familymemberhasaccount } 1 \text { yesp }\end{array}$}} & & .1770294 & .0726592 & 2.44 & 0.015 & .0340957 & .319963 \\
\hline & & & -.0257115 & .0751694 & -0.34 & 0.733 & -.1735831 & .1221601 \\
\hline \multicolumn{2}{|c|}{ Lackoftrustiyesono } & & .4594403 & .1141577 & 4.02 & 0.000 & .2348717 & .6840089 \\
\hline \multicolumn{2}{|c|}{ Religiousbarrlyesono } & & -.0477907 & .1379195 & -0.35 & 0.729 & -.319103 & .2235215 \\
\hline \multicolumn{2}{|r|}{ _cons } & & .3121915 & .0292691 & 10.67 & 0.000 & .2546139 & .3697691 \\
\hline
\end{tabular}

Source: Authors analysis of regression output on barriers to inclusion, 2016.

Table 2. Breusch-Pagan / Cook-Weisberg test for heteroskedasticity

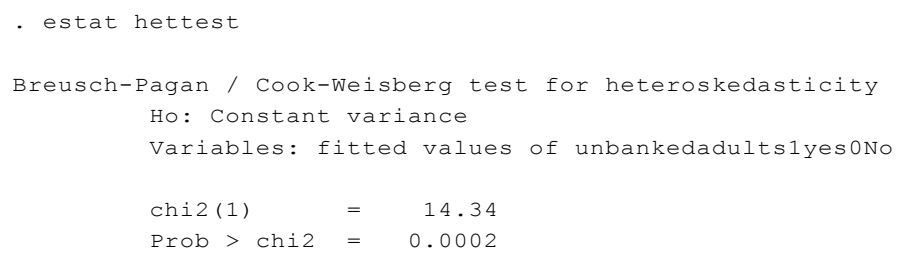


Table 3. Ramsey RESET test using powers of the fitted values of unbankedadults1yes0No

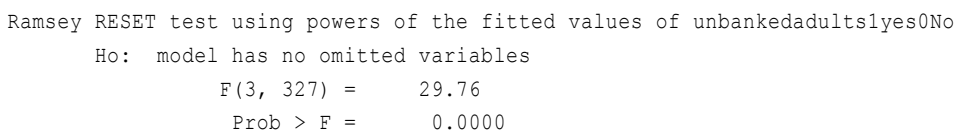

Table 4. Correlation Matrix

\begin{tabular}{|c|c|c|c|c|c|c|c|c|c|}
\hline e (V) & Lacko 0p & Lacko sp & Toofar o & Tooexp O & lackof $\sim p$ & Family p & Lackof 0 & Religi o & _cons \\
\hline LackofMon $0 \mathrm{p}$ & 1.0000 & & & & & & & & \\
\hline LackofMon sp & -0.0175 & 1.0000 & & & & & & & \\
\hline Toofaraway o & -0.4228 & 0.1501 & 1.0000 & & & & & & \\
\hline Tooexpensi o & -0.3551 & 0.1122 & 0.1300 & 1.0000 & & & & & \\
\hline lackofnece p & -0.2668 & 0.0578 & 0.1158 & -0.2830 & 1.0000 & & & & \\
\hline Familymemb p & -0.2071 & 0.0221 & -0.1932 & -0.0431 & -0.0622 & 1.0000 & & & \\
\hline Lackoftrus o & -0.1892 & 0.0609 & 0.2610 & 0.0766 & 0.1731 & -0.3406 & 1.0000 & & \\
\hline Religiousb o & -0.1036 & 0.0441 & 0.1238 & -0.1121 & 0.0127 & -0.0300 & 0.0750 & 1.0000 & \\
\hline _cons & -0.0982 & -0.4616 & -0.3265 & -0.2174 & -0.0949 & 0.0109 & -0.1722 & -0.0709 & 1.0000 \\
\hline
\end{tabular}

\section{Copyright Disclaimer}

Copyright for this article is retained by the author(s), with first publication rights granted to the journal.

This is an open-access article distributed under the terms and conditions of the Creative Commons Attribution license (http://creativecommons.org/licenses/by/3.0/). 